\title{
Rancang Bangun Alat Pendeteksi Kebisingan Berbasis Sensor Serat Optik
}

\author{
Sixtinah Deswilan*, Harmadi \\ Laboratorium Elektronika dan Instrumentasi, Jurusan Fisika, \\ Fakultas Matematika dan Ilmu Pengetahuan Alam, Universitas Andalas \\ Kampus Unand Limau Manis, Padang, 25163, Indonesia \\ *sixtinahd@gmail.com
}

\begin{abstract}
ABSTRAK
Telah dilakukan rancang bangun alat pendeteksi kebisingan berbasis sensor serat optik dengan metode ekstrinsik. Alat pendeteksi kebisingan terdiri dari sensor serat optik yang menggunakan sumber cahaya berupa dioda laser, serat optik FD-620-10 step index multimode dan fotodetektor OPT101. Sensor serat optik digunakan untuk mengukur frekuensi dan tingkat tekanan bunyi dengan memanfaatkan perubahan tegangan keluaran. Perubahan tegangan keluaran terjadi akibat adanya variasi jarak membran terhadap serat optik. Pengujian pertama dilakukan uji coba alat ukur dengan alat pembanding dan aplikasi frequency generator. Hasil pengujian menunjukkan bahwa pada pengukuran frekuensi $1000 \mathrm{~Hz}$ sampai $5000 \mathrm{~Hz}$ memiliki presentase kesalahan rata-rata 4,65\% serta tingkat tekanan bunyi memiliki presentase kesalahan rata-rata 3,30\%. Pengujian kedua dilakukan di dalam ruangan menghasilkan rentang frekuensi sekitar $1000 \mathrm{~Hz}$ sampai $9000 \mathrm{~Hz}$ dengan tingkat tekanan bunyi alat ukur $47 \mathrm{~dB}$ sampai $86 \mathrm{~dB}$ dan alat pembanding 53,8 dB sampai 58,2 dB serta persentase kesalahan rata-rata $1,51 \%$ dan $1,67 \%$.

Kata Kunci : bunyi, frekuensi, kebisingan, membran, serat optik.
\end{abstract}

\section{ABSTRACT}

A noise detector has been designed based on optical fiber sensors with extrinsic method. The noise detector device consist of an optical fiber sensor using a light source of a laser diode, an optical fiber FD-620-10 step index multimode and OPT101 a photodetector. The sensor was used to measure the frequency and sound pressure level by utilizing the output voltage change. Changes in the voltage occur due to the variation of membrane distance to optical fibers. The first test were using measuring instrument with MS6300 comparison tool and frequency generator application. It show that at $1000 \mathrm{~Hz}$ to $5000 \mathrm{~Hz}$ frequency, the average error percentage is $4.65 \%$ and the sound pressure level test, the average error is 3.30\%. The second test was tasted by doing into the room, it shows at $1000 \mathrm{~Hz}$ to $9000 \mathrm{~Hz}$ frequency with sound pressure level detected by measuring instrument at $47 d B$ to $86 d B$ and by comparative tool at $53.8 \mathrm{~dB}$ to $58.2 \mathrm{~dB}$ as well as the average error percentage is $1.51 \%$ and $1.67 \%$.

Keywords: frequency, membrane, noise, optical fiber, sound.

\section{PENDAHULUAN}

Kebisingan adalah bunyi yang tidak diinginkan dari usaha atau kegiatan pada tingkat dan waktu tertentu dapat menimbulkan gangguan kesehatan dan kenyamanan lingkungan (Kepmen LH No.48, 1996). Kebisingan dapat berasal dari bunyi mesin yang menghasilkan nilai frekuensi dan tingkat tekanan bunyi berbeda-beda. Semakin tinggi tingkat tekanan bunyi yang dihasilkan dari sumber kebisingan, maka akan semakin besar dampak dari kebisingan yang ditimbulkan (Syamsul dan Widianti, 2018). Seiring dengan meningkatnya tekanan bunyi yang dihasilkan dari sumber kebisingan. Bunyi yang dihasilkan tersebut akan berpengaruh dalam kegiatan belajar mengajar. Bunyi yang telah melewati ambang batas kebisingan $55 \mathrm{~dB}$, tidak direkomendasikan pada area sekolah (Metawati, 2013).

Perancangan alat pendeteksi kebisingan telah dilakukan oleh Suryanto dan Hisam (2010) yaitu perancangan dan pembuatan alat pendeteksi tingkat kebisingan berbasis mikrokontroler. Alat ini dapat menampilkan nilai kebisingan berdasarkan tingkat tekanan bunyi yang dideteksi oleh mikrofon dinamik pada sebuah display dot matrix. Alat tersebut dapat mendeteksi tingkat tekanan bunyi rata-rata dalam rentang $58 \mathrm{~dB}$ sampai $95 \mathrm{~dB}$. Penelitian tersebut masih memiliki kekurangan karena penggunaan mikrofon dinamik dianggap kurang sensitif. Mikrofon dinamik membutuhkan getaran akustik yang kuat untuk menggerakkan kumparan yang terdapat di dalam medan magnet untuk menghasilkan tegangan. Pemilihan sensor bunyi yang tepat diperlukan dalam meningkatkan sensitifitas alat untuk mendeteksi bunyi berdasarkan nilai frekuensi getaran akustik dan tingkat tekanan bunyi. 
Penggunaan sensor serat optik merupakan pilihan yang tepat untuk mendeteksi kebisingan kerena gelombang bunyi terpandu tanpa ada noise akibat gangguan medan elektromagnetik dan gelombang radio (Herman, 2013). Penelitian mengenai sensor serat optik telah dilakukan oleh Putri dan Harmadi (2017) untuk mendeteksi frekuensi getaran akustik pada speaker piezoelektrik. Frekuensi geteran yang diukur dengan rentang $1000 \mathrm{~Hz}-40.000 \mathrm{~Hz}$. Alat tersebut memiliki tingkat ketelitian 99,97\%, tingkat kesalahan 0,007\% dan standar deviasi sebesar 0,03 .

Berdasarkan permasalahan dan hasil penelitian yang telah dilakukan oleh beberapa peneliti sebelumnya, maka diperlukan penelitian dengan rancangan alat lebih terpadu untuk mendeteksi kebisingan ruangan. Sistem sensor akan dirancang menggunakan serat optik tipe step index multimode, diode laser dan fotodetektor OPT101. Alat pendeteksi kebisingan berbasis sensor serat optik akan diaplikasikan pada ruangan kuliah dan Laboratorium. Penelitian ini diharapkan dapat membantu civitas akademika dalam memonitoring tingkat kebisingan ruangan.

\section{METODE}

\subsection{Alat dan Bahan}

Alat yang digunakan dalam perancangan ini meliputi dioda laser, serat optik tipe FD620-10 step index multimode, fotodetektor OPT101, pre-ampifier BC547 dan LM386, LCD I2C, LED dot matrix dan mikrokontroler arduino uno.

\subsection{Perancangan Perangkat Keras Sensor Kebisingan}

Rancangan perangkat keras sistem sensor kebisingan menggunakan serat optik sebagai sensornya adalah seperti Gambar 1. Sistem perangkat keras ini terdiri dari dioda laser sebagai sumber cahaya mengenai serat optik transmitter. Cahaya tersebut kemudian dipandu menuju membran spondel mikrofon sebagai sumber getar. Jika terdapat suara yang berasal dari lingkungan luar, maka membran akan mengalami variasi jarak yang mengakibatkan terjadinya variasi intensitas cahaya yang masuk ke serat optik receiver. Cahaya yang dipandu melalui serat optik receiver akan dideteksi oleh OPT101 sebagai fotodetektor. OPT101 menghasilkan sinyal keluaran berupa tegangan listrik yang akan diproses oleh Arduino Uno R3. Sinyal keluaran tersebut akan menghasilkan besaran fisis berupa frekuensi dan tingkat tekanan bunyi pada layar LCD serta indikator peringatan dengan tulisan "harap diam" pada LED dot matrix.

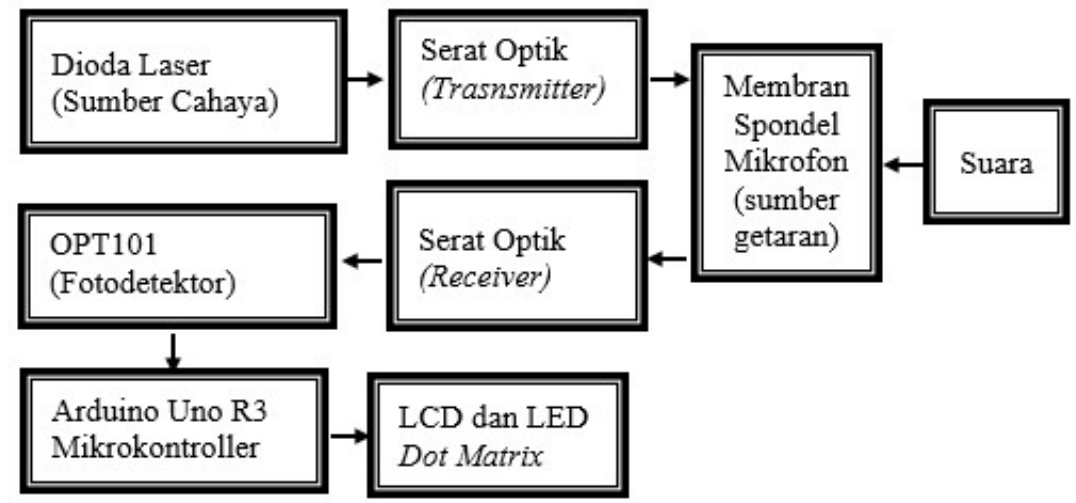

Gambar 1 Diagram blok sistem sensor kebisingan berbasis sensor serat optik

\subsection{Perancangan dan Karakterisasi Mikrofon Serat Optik}

Karakterisasi mikrofon serat optik terdiri dari perancangan sensor bunyi menggunakan dioda laser sebagai sumber cahaya. Serat optik digunakan sebagai medium yang menghantarkan cahaya yang diterima dari dioda laser. Membran spondel mikrofon dan bunyi sebagai objek yang akan diukur. Perancangan dan karakterisasi mikrofon serat optik dapat dilihat pada Gambar 2. 


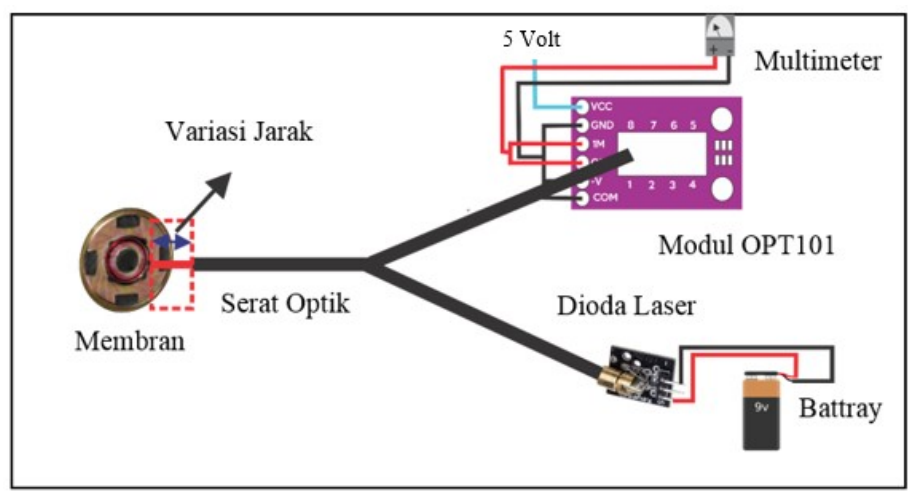

Gambar 2 Skema karakterisasi sensor

\subsection{Perancangan Perangkat Lunak Sistem Sensor}

Perancangan perangkat lunak bertujuan untuk memproses sinyal masukan dari sensor serat optik. Pemrograman pada penelitian ini terdiri dari source code yang ditanamkan pada mikrokontroler arduino uno menggunakan bahasa $\mathrm{C}$. Tingkat tekanan bunyi yang menjadi acuan adalah $55 \mathrm{~dB}$. Apabila nilai tingkat tekanan bunyi melewati batas ambang kebisingan maka pada layar LCD akan ditampilkan nilai frekuensi dan tingkat tekanan bunyi serta indikator peringatan dengan tulisan "Harap Diam" pada LED dot matrix. Secara umum diagram alir program pengukuran tingkat tekanan bunyi yang menimbulkan kebisingan terlihat pada Gambar 3.

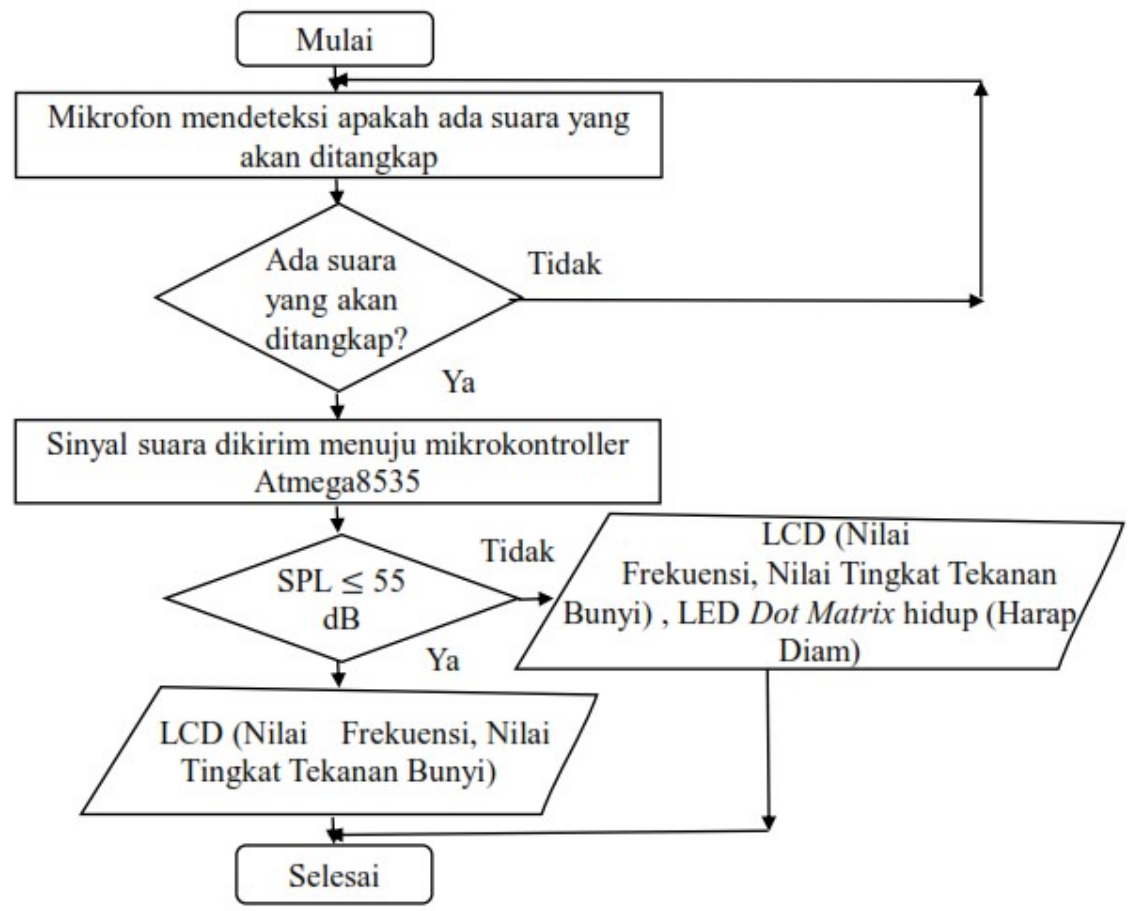

Gambar 3 Diagram alir program pengukuran kebisingan

\subsection{Pengujian Sistem Pendeteksi dan Pengambilan Data}

Pengujian dan pengambilan data dilakukan dengan cara membandingkan hasil pengukuran pada alat ukur yang telah dirancang dengan alat ukur standar yaitu MS6300. Sumber bunyi menggunakan aplikasi frequency generator yang ada pada android. Alat pembanding berupa MS6300 dapat menentukan tingkat ketelitian dari alat yang dirancang. Ketepatan dari sistem dapat ditentukan dari persentase kesalahan antara nilai aktual dengan nilai terlihat. Besar persentase kesalahan pada pengujian skala suatu alat ukur dapat ditentukan dengan persentase kesalahan $X Y$ dan persentase ketepatan $A_{n}$ (Saputro, 2014). 


$$
X Y=\left|\frac{Y_{n}-X_{n}}{Y_{n}}\right| \times 100 \%
$$

Persamaan (1) menunjukkan nilai persentase kesalahan, $Y_{n}$ adalah nilai sebenarnya pada alat pembanding dan $X_{n}$ adalah nilai yang terbaca pada alat ukur. Persentase ketepatan $A_{n}$ dapat dilihat pada Persamaan (2).

$$
A_{n}=\left[1-\left|\frac{Y_{n}-X_{n}}{Y_{n}}\right|\right] \times 100 \%
$$

Ketika alat yang dirancang sudah dikarakterisasi dengan alat pembanding maka akan dilakukan pengujian langsung diruangan. Ruangan uji coba adalah ruang kuliah D dan Laboratorium.1

\section{HASIL DAN DISKUSI}

\subsection{Karakterisasi Fotodetektor OPT101}

Karakterisasi fotodetektor OPT101 dilakukan untuk mendeteksi pengaruh perubahan intensitas cahaya yang dipandu oleh serat optik receiver terhadap nilai tegangan yang dihasilkan. Pengujian fotodetektor OPT101 dan alat pembanding luxmeter dilakukan di ruangan gelap dan tertutup, sehingga intensitas cahaya dapat divariasikan menggunakan bantuan senter sebagai sumber cahaya. Hasil pengujian fotodetektor OPT101 dapat dilihat pada Tabel 1.

Tabel 1 Data pengujian tegangan keluaran OPT101

\begin{tabular}{cc}
\hline $\begin{array}{c}\text { Intensitas Cahaya } \\
\text { (lux) }\end{array}$ & Vout (mV) \\
\hline 0 & 0,0077 \\
0,5 & 0,4540 \\
3,6 & 0,4710 \\
15,8 & 0,5420 \\
38,4 & 0,6710 \\
89,7 & 0,9670 \\
138 & 1,3360 \\
344 & 2,9760 \\
454 & 3,7330 \\
604 & 4,2100 \\
\hline
\end{tabular}

Berdasarkan Tabel 1 didapatkan hasil hubungan antara intensitas cahaya dan tegangan keluaran. Pengujian fotodetektor OPT101 dan luxmeter menghasilkan nilai tegangan yang semakin besar seiring dengan meningkatnya intensitas cahaya yang diterima oleh fotodetektor OPT101.

\subsection{Karakterisasi Sensor Serat Optik}

Karakterisasi sensor serat optik dilakukan dengan tujuan untuk menggambarkan kemampuan serat optik dalam mendeteksi tegangan keluaran terhadap variasi jarak. Variasi jarak dilakukan antara ujung sensor serat optik dengan membran spondel mikrofon. Data pengujian karakterisasi sensor serat optik dapat dilihat pada Tabel 2.

Tabel 2 merupakan data perubahan jarak antara membran dan serat optik terhadap tegangan keluaran fotodetektor OPT101. Data pengujian mengalami peningkatan pada jarak 0 $\mathrm{mm}-1 \mathrm{~mm}$, kemudian semakin menurun menuju angka nol seiring bertambahnya jarak antara sensor serat optik dengan membran. Nilai tertinggi terjadi pada jarak $2 \mathrm{~mm}$ dengan tegangan keluaran $452 \mathrm{mV}$. Nilai tertinggi tersebut berada dalam rentang numerical aperture (NA) serat optik. Karakterisasi ini menjadi patokan untuk menentukan jarak terbaik untuk menempatkan sensor serat optik dan membran, yaitu pada jarak $2 \mathrm{~mm}$. 
Tabel 2 Data pengujian jarak antara membran dan serat optik terhadap tegangan keluaran fotodetektor OPT101

\begin{tabular}{cc}
\hline Jarak (mm) & $\mathbf{V}_{\text {out }}$ Rata-Rata $(\mathbf{m V})$ \\
\hline 0 & 155,00 \\
1 & 174,78 \\
2 & 452,00 \\
3 & 372,56 \\
4 & 276,44 \\
5 & 227,46 \\
6 & 199,30 \\
7 & 181,48 \\
8 & 168,86 \\
9 & 167,26 \\
10 & 157,76 \\
\hline
\end{tabular}

\subsection{Hasil Pengujian Alat Pendeteksi Dengan Alat Pembanding}

Pengujian alat dilakukan untuk melihat keakuratan dari alat yang telah dirancang. Pengujian dilakukan dengan cara membandingkan alat ukur dengan alat pembanding MS6300 dengan menggunakan variasi nilai frekuensi dari aplikasi frequency generator. Nilai frekuensi bersumber dari bunyi yang dihasilkan oleh aplikasi frequency generator dengan rentang frekuensi $1000 \mathrm{~Hz}$ sampai $5000 \mathrm{~Hz}$. Nilai frekuensi yang dihasilkan oleh aplikasi frequency generator akan dideteksi oleh alat ukur. Hasil dari pengujian tersebut mengahasilkan 9 data dengan presentase kesalahan rata-rata 4,65\% dan persentase ketepatan rata-rata 95,35\%. Data perbandingan nilai frekuensi dari aplikasi frequency generator dan alat ukur dapat dilihat pada Tabel 3.

Tabel 3 Grafik perbandingan nilai frekuensi pada aplikasi frequency generator dan hasil pengujian menggunakan alat pendeteksi kebisingan dengan serat optik

\begin{tabular}{cccc}
\hline $\begin{array}{c}\text { Frekuensi Alat } \\
\text { Pembanding (Hz) }\end{array}$ & $\begin{array}{c}\text { Frekuensi Alat } \\
\text { Ukur (Hz) }\end{array}$ & $\begin{array}{c}\text { Persentase } \\
\text { Kesalahan (\%) }\end{array}$ & $\begin{array}{c}\text { Persentase } \\
\text { Ketepatan (\%) }\end{array}$ \\
\hline 1016 & 925 & $8,96 \%$ & $91,04 \%$ \\
1509 & 1350 & $10,54 \%$ & $89,46 \%$ \\
2012 & 2025 & $0,65 \%$ & $99,35 \%$ \\
2542 & 2475 & $2,64 \%$ & $97,36 \%$ \\
3043 & 2925 & $3,88 \%$ & $96,12 \%$ \\
3513 & 3600 & $2,48 \%$ & $97,52 \%$ \\
4057 & 4275 & $5,37 \%$ & $94,63 \%$ \\
4519 & 4725 & $4,56 \%$ & $95,44 \%$ \\
5034 & 5175 & $2,80 \%$ & $97,20 \%$ \\
\hline \multicolumn{4}{c}{ Rata-Rata } \\
\hline
\end{tabular}

Berdasarkan sumber bunyi dari aplikasi frequency generator, nilai tingkat tekanan bunyi akan dideteksi oleh alat ukur dan alat pembanding MS6300. Hasil pengujian tersebut menghasilkan nilai tingkat tekanan bunyi dengan presentase kesalahan rata-rata 3,30\% dan persentase ketepatan rata-rata $96,70 \%$. Data perbandingan nilai tingkat tekanan bunyi alat pembading MS6300 dan alat ukur dapat dilihat pada Tabel 4.

Pengujian yang telah dilakukan menghasilkan persentase kesalahan rata-rata kecil dari 5\%. Berdasarkan data statistik yang diperoleh dapat disimpulkan bahwa rancangan sistem alat pendeteksi menggunakan sensor serat optik telah berhasil dilakukan untuk range frekuensi yang dapat didengar oleh telinga manusia. 
Tabel 4 Grafik perbandingan nilai tingkat tekanan bunyi pada MS6300 dan hasil pengujian menggunakan alat pendeteksi kebisingan dengan serat optik

\begin{tabular}{cccc}
\hline $\begin{array}{c}\text { Tingkat Tekanan } \\
\text { Bunyi Alat } \\
\text { Pembanding (dB) }\end{array}$ & $\begin{array}{c}\text { Tingkat Tekanan } \\
\text { Bunyi Alat Ukur } \\
\text { (dB) }\end{array}$ & $\begin{array}{c}\text { Persentase } \\
\text { Kesalahan (\%) }\end{array}$ & $\begin{array}{c}\text { Persentase } \\
\text { Ketepatan (\%) }\end{array}$ \\
\hline 44.3 & 47 & $6,09 \%$ & $93,91 \%$ \\
47.1 & 49 & $4,03 \%$ & $95,97 \%$ \\
50.7 & 52 & $2,56 \%$ & $97,44 \%$ \\
53.1 & 54 & $1,69 \%$ & $98,31 \%$ \\
55.4 & 56 & $1,08 \%$ & $98,92 \%$ \\
57.2 & 59 & $3,15 \%$ & $96,85 \%$ \\
63.8 & 62 & $2,82 \%$ & $97,18 \%$ \\
66.2 & 64 & $3,32 \%$ & $96,68 \%$ \\
69.4 & 66 & $4,90 \%$ & $95,10 \%$ \\
\hline \multicolumn{4}{c}{ Rata-Rata } \\
\hline
\end{tabular}

\subsection{Hasil Pengujian Alat di Ruangan}

Alat yang telah diuji, kemudian diaplikasikan ke dalam suatu ruangan. Proses uji coba alat dilakukan di dua rungan yaitu ruang kuliah D dan Laboratorium Elektronika dan Instrumentasi. Pengujian alat dilakukan sebanyak 3 kali percobaan dengan rentang waktu 30 menit sehingga diperoleh sebanyak 1801 data. Alat pendeteksi kebisingan melakukan proses pendataan secara real time sampai waktu telah terpenuhi.

Waktu pengujian alat di Gedung kuliah disesuaikan dengan kondisi jadwal perkuliahan. Alat pendeteksi kebisingan dapat mendeteksi kebisingan yang melewati batas ambang kebisingan $55 \mathrm{~dB}$ sebanyak 2 kali dengan diiringi peringatan yang ditampilkan pada LED dot matrix. Data pengujian alat di Gedung kuliah dapat dilihat pada Tabel 5. Nilai tingkat tekanan bunyi paling tinggi berada pada nilai $59 \mathrm{~dB}$ yang terjadi pada 30 menit pertama. Pengujian kedua dilakukan di Laboratorium Elektronika dan Instrumentasi Fisika Unand. Alat pendeteksi kebisingan dapat merespon bunyi dengan baik. Kondisi kebisingan yang dideteksi sebanyak 3 kali dalam rentang 30 menit. Data pengujian alat pada Laboratorium dapat dilihat pada Tabel 6. Nilai tingkat tekanan bunyi rata-rata paling tinggi berada pada nilai $59 \mathrm{~dB}$ yang terjadi pada 30 menit pertama dan kedua.

Tabel 5 Data pengujian alat pendeteksi kebisingan berbasis sensor serat optik di Gedung Kuliah D Universitas Andalas

\begin{tabular}{ccccc}
\hline $\begin{array}{c}\text { Waktu } \\
\text { Pengukuran }\end{array}$ & $\begin{array}{c}\text { Tingkat Tekanan } \\
\text { Bunyi Rata-Rata } \\
\text { Alat Ukur (dB) }\end{array}$ & $\begin{array}{c}\text { Tingkat Tekanan Bunyi } \\
\text { Rata-Rata Alat } \\
\text { Pembanding (dB) }\end{array}$ & $\begin{array}{c}\text { Persentase } \\
\text { Kesalahan (\%) }\end{array}$ & $\begin{array}{c}\text { Indikator } \\
\text { Peringatan LED } \\
\text { Dot Matrix }\end{array}$ \\
\hline $09.50-10.20$ & 59 & 57,7 & $2,25 \%$ & Hidup \\
$10.30-11.00$ & 58 & 56,9 & $1,93 \%$ & Hidup \\
$11.10-11.40$ & 54 & 53,8 & $0,37 \%$ & Mati \\
\hline \multicolumn{7}{c}{ Rata-Rata } & & $1,51 \%$ & \\
\hline
\end{tabular}

Tabel 6 Data pengujian alat pendeteksi kebisingan berbasis sensor serat optik di Laboratorium Elektronika dan Instrumentasi

\begin{tabular}{ccccc}
\hline $\begin{array}{c}\text { Waktu } \\
\text { Pengukuran }\end{array}$ & $\begin{array}{c}\text { Tingkat Tekanan } \\
\text { Bunyi Rata-Rata } \\
\text { Alat Ukur (dB) }\end{array}$ & $\begin{array}{c}\text { Tingkat Tekanan Bunyi } \\
\text { Rata-Rata Alat } \\
\text { Pembanding (dB) }\end{array}$ & $\begin{array}{c}\text { Persentase } \\
\text { Kesalahan (\%) }\end{array}$ & $\begin{array}{c}\text { Indikator } \\
\text { Peringatan LED } \\
\text { Dot Matrix }\end{array}$ \\
\hline $10.00-10.30$ & 59,0 & 58,2 & $1,37 \%$ & Hidup \\
$10.40-11.10$ & 59,0 & 57,8 & $2,07 \%$ & Hidup \\
$11.20-11.50$ & 58,0 & 57,1 & $1,57 \%$ & Hidup \\
\hline \multicolumn{5}{c}{ Rata-Rata } \\
\hline
\end{tabular}

Berdasarkan pengujian di dua ruangan berbeda didapatkan rentang frekuensi $1000 \mathrm{~Hz}$ sampai $9000 \mathrm{~Hz}$ dengan tingkat tekanan bunyi rata-rata alat ukur $54 \mathrm{~dB}$ sampai $59 \mathrm{~dB}$ dan alat pembanding 53,8 dB sampai 58,2 dB. Pengujian alat pada ruangan dapat membuktikan bahwa 
alat yang telah dirancang dapat digunakan di dalam ruangan sehingga dapat memonitoring kebisingan yang terjadi di dalam ruangan.

\section{KESIMPULAN}

Berdasarkan pengujian dan analisis yang telah dilakukan, maka dapat disimpulkan bahwa rancangan sistem pendeteksi kebisingan berbasis sensor serat optik telah mampu mengukur frekuensi dan tingkat tekanan bunyi secara akurat. Hasil pengukuran frekuensi menunjukkan terdapat persentase kesalahan rata-rata $4,65 \%$ dan persentase ketepatan rata-rata $95,35 \%$ serta tingkat tekanan bunyi dengan persentase kesalahan rata-rata $3.30 \%$ dan persentase ketepatan rata-rata $96,70 \%$. Hasil pengujian pada ruangan telah dapat mendeteksi tingkat tekanan bunyi dalam rentang $47 \mathrm{~dB}$ sampai $86 \mathrm{~dB}$ selama 6 kali percobaan di 2 ruangan berbeda. Nilai pengukuran frekuensi dan tigkat tekanan bunyi telah dapat dilakukan secara real time dengan ditampilkan secara langsung pada LCD dan peringatan batas kebisigan pada LED dot matrix.

\section{UCAPAN TERIMA KASIH}

Dalam terlaksananya penelitian ini banyak pihak yang membantu penulis sehingga dapat menyelesaikannya tepat waktu. Penulis mengucapkan terima kasih kepada Kementrian Riset, Teknologi dan Pendidikan Tinggi Republik Indonesia (Kemenristekdikti) yang telah memberikan bantuan dana penelitian melalui Program Kreativitas Mahasiswa (PKM).

\section{DAFTAR PUSTAKA}

Herman, Rancang Bangun Mikrofon Berbasis Serat Optik, Jurnal Cakrawala Pendidikan, 4, 63 69 (2013).

Kepmen LH No. 48, 1996, Baku Tingkat Kebingan, Depdiknas, Jakarta.

Metawati, N., Evaluasi Pemenuhan Standar Tingkat Kebisingan Kelas di SMPN 23 Bandung (Perpustakaan UPI, Bandung, 2013), hal. 137-140.

Suryanto dan Hisam, A., Perancangan dan Pembuatan Alat Pendeteksi Kebisingan Bunyi Berbasis Mikrokontroler, Jurnal Fisika dan Aplikasinya, 6, 1-4 (2010).

Syamsul dan Widianti, S. Y., Rancang Bangun Pengontrolan dan Monitoring Kebisingan Ruangan Berbasis Mikrokontroler AVR ATMega 8535, Journal of Electrical Technology, 3, 22-26 (2018).

Putri, S. E. dan Harmadi, Rancang Bangun Sistem Pengukuran Frekuensi Getaran Akustik pada Speaker Piezoelektrik Menggunakan Sensor Serat Optik, Jurnal Fisika UNAND, 6, 47 52 (2017). 